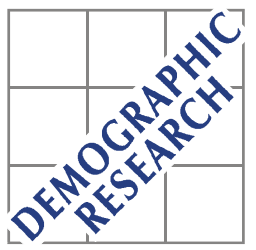

Demographic Research a free, expedited, online journal

of peer-reviewed research and commentary in the population sciences published by the Max Planck Institute for Demographic Research

Konrad-Zuse Str. 1, D-18057 Rostock · GERMANY

www.demographic-research.org

DEMOGRAPHIC RESEARCH

VOLUME 22, ARTICLE 14, PAGES 347-382

PUBLISHED 12 MARCH 2010

http://www.demographic-research.org/Volumes/Vol22/14/

DOI: $10.4054 /$ DemRes.2010.22.14

Research Article

Marriage choices and social reproduction:

The interrelationship between

partner selection and

intergenerational socioeconomic

mobility in $19^{\text {th }}$-century Sweden

\title{
Martin Dribe
}

\section{Christer Lundh}

This publication is part of the proposed Special Collection "Social Mobility and Demographic

Behaviour: A Long-Term Perspective", organized by Guest Editors Cameron Campbell, Jan Van Bavel, and Martin Dribe.

(C) 2010 Martin Dribe \& Christer Lundh.

This open-access work is published under the terms of the Creative Commons Attribution NonCommercial License 2.0 Germany, which permits use,

reproduction \& distribution in any medium for non-commercial purposes,

provided the original author(s) and source are given credit.

See http:// creativecommons.org/licenses/by-nc/2.0/de/ 


\section{Table of Contents}

$\begin{array}{lll}1 & \text { Introduction } & 348\end{array}$

2 Background $\quad 349$

$3 \quad$ Area and data 355

4 Methods $\quad 357$

$\begin{array}{lll}5 & \text { Results } & 359\end{array}$

$\begin{array}{lll}6 & \text { Conclusions } & 373\end{array}$

$7 \quad$ Acknowledgement 375

$\begin{array}{ll}\text { References } & 376\end{array}$ 


\title{
Marriage choices and social reproduction: The interrelationship between partner selection and intergenerational socioeconomic mobility in $19^{\text {th }}$-century Sweden
}

\author{
Martin Dribe ${ }^{1}$ \\ Christer Lundh ${ }^{2}$
}

\begin{abstract}
This article studies the relationship between partner selection and socioeconomic status (SES) attainment and mobility in five rural parishes in southern Sweden, 1815-1894. Three different aspects of partner selection are considered: age, social origin, and geographical origin. We use an individual-level database containing information on the SES origin (parental land holding and occupation), age difference, and place of birth of the married couple. The results show a powerful association between partner selection and SES attainment and mobility. Social heterogamy was particularly important, but age heterogamy and geographic exogamy was also clearly related to both SES attainment and mobility.
\end{abstract}

\footnotetext{
${ }^{1}$ Associate Professor, PhD, Centre for Economic Demography and Department of Economic History, Lund University. P.O. Box 7083. 22007 Lund, Sweden. E-mail: Martin.Dribe@ekh.lu.se. Phone: +46462224677. Fax: +46462227339 .

${ }^{2}$ Professor, PhD, Department of Economic History. University of Gothenburg.

E-mail: Christer.Lundh@econhist.gu.se.
} 


\section{Introduction}

In preindustrial society, socioeconomic status (SES) was a crucial determinant of the living conditions of individuals and families. Most prominently, SES determined the access to economic resources, thereby reflecting group-specific differences in the standard of living in terms of nutrition, housing, and vulnerability to economic hardship (see, e.g. Allen, Bengtsson, and Dribe 2005; Bengtsson et al. 2004; Dribe 2000: Ch. 3; Winberg 1975). Thus, individuals and families of higher SES generally had better living conditions than those of lower SES. In addition, a higher SES meant greater prestige in the local community and access to better SES networks, which, in turn, could influence opportunities for accumulating resources. Although less important in reality than it is often assumed, SES also had implications for demographic behavior. For example, there seem to have been considerable differences between different socioeconomic groups in terms of fertility, marriage, and migration, at least in some historical contexts (see, e.g., Bengtsson and Dribe 2006; Dribe 2000, 2003; Manfredini 2003; Tsuya et al. 2010). However, there is not much solid evidence of large SES differences in mortality and life expectancy in preindustrial society (Edvinsson 1992; Livi-Bacci 1991; Razzel and Spence 2006; Smith 1983).

Socioeconomic status in pre-modern society was determined by a range of different factors. SES attainment could, in part, be linked to individual achievement, through investments in education, training, and networks. These are the kinds of factors that we often assume to be dominant in contemporary societies, even though we know that various intergenerational factors are of considerable importance as well. For example, there is still a considerable socioeconomic bias in higher education towards students from highly educated backgrounds, even though it is less pronounced today than half a century ago (Breen and Jonsson 2005; Jonsson and Erikson 2000). In rural societies, these inherited factors were of great importance for SES attainment, which is perhaps best seen in the primacy of access to land for socioeconomic attainment in most rural societies. Even in cases where land could be purchased in the market, having landholding parents was most likely a major advantage.

One means of accessing economic resources, networks, or social prestige in the absence of inherited assets could have been through the marriage market. By finding a spouse from a higher SES origin, an individual might have increased the chances of advancing to a higher SES. On the other hand, marrying someone with a lower SES increased the risk of downward socioeconomic mobility. Hence, finding a spouse from the same socioeconomic status (SES homogamy) could be seen as an important strategy, especially among landholding farmers wishing to maintain their landholding status and secure their social reproduction (see, e.g., Bourdieu 1976). Partner selection was thus a crucial issue in preindustrial society, involving a lot more than love and 
affection (e.g. Cherlin 2004; Coontz 2004; Mitterauer and Sieder 1982: Ch. 6; Shorter 1977: Ch. 2; Stone 1977, Ch. 7).

In this article, we study the interrelationships of different aspects of partner selection on the one hand, and SES attainment and intergenerational SES mobility on the other. We assess the effects of partner selection based SES origin, age, and place of birth-controlling for own SES origin, place of birth, and birth date-using longitudinal data on individuals based on family reconstructions and population registers for five parishes in southern Sweden during the period 1815-1894. Individual occupations have been coded in HISCO and classified into HISCLASS. We use the occupational information, together with data on size of landholdings and type of tenure, in constructing a SES classification which captures the realities of the communities studied. This article refers to two previous studies on the same topic: one dealing with social mobility more generally, using a cruder socioeconomic classification (Dribe and Svensson 2008); and one on occupational homogamy and its relationship to occupational attainment and mobility (Dribe and Lundh 2009b). Compared to the latter, this study has a wider focus on partner selection dealing with SES homogamy, age homogamy, and geographic endogamy. In addition, instead of focusing on occupation, this article looks at SES by combining data on the size and type of land holding with occupational data for the landless groups.

\section{Background}

We know from previous research that there was considerable social mobility in preindustrial society, despite the long-held popular image of preindustrial society as being stationary, both geographically and socioeconomically (see the discussion in Dribe and Svensson 2008). Much of the evidence available comes from urban areas, where the socioeconomic and occupational structures were different from those of the rural areas (see, e.g., Maas and van Leeuwen 2002; Van Leeuwen and Maas 1991, 1996). In rural areas, downward mobility appears to have been more frequent than upward mobility, and it also seems to have increased following the agricultural transformation of the early $19^{\text {th }}$-century (see, e.g., Dribe and Lundh 2009b; Dribe and Svensson 2008; Eriksson and Rogers 1978; Lundh 1999; Winberg 1975). In a longerterm perspective, social mobility upwards might have become increasingly important following modernization, and connected to individualization and increased meritocracy (e.g., Blau and Duncan 1967). However, there does not appear to be any clear and simple relationship between the degree of industrialization and social mobility in the group of 20th-century Western countries studied by Erikson and Goldthorpe (1993) in their path-breaking study of social mobility in industrialized countries. 
Previous studies have also stressed the importance of both inherited factors and individual agency as determinants of socioeconomic attainment and mobility. Particularly in rural areas, access to land, the main productive resource, was a major determinant of socioeconomic attainment, and hence originating in the landed groups of the population greatly increased the chances of ending up as a landed farmer (Dribe and Svensson 2008). Individual action and ability could also be important, and investments in education, training, and networks could represent paths to social advancement.

One important means of investing in future socioeconomic status was finding the right partner. Many studies have confirmed the prevalence of socioeconomic homogamy in preindustrial societies, especially among landholding farmers (e.g. Arrizabalaga 2005; Bras and Kok 2005; Bull 2005; Dribe and Lundh 2005a; Van Leeuwen and Maas 2002). This could, at least to some extent, be viewed as an indication of the strategic and instrumental nature of preindustrial marriages (cf. Mitterauer and Sieder 1982: Ch. 6; Shorter 1972: Ch. 2; Stone 1977, Ch. 7). Partner selection is thus potentially one of most important factors contributing to socioeconomic status and mobility besides the individual's own socioeconomic origin.

In general, we expect partner selection to depend on three factors: preferences, marriage market structure, and third-party influence (Kalmijn 1998). First, culturally derived individual preferences steer union formation in a certain direction. It is easy to imagine such preferences with regard to ethnicity or religion (Gordon 1964). Historical studies report negative attitudes of city populations towards immigrants from rural areas (Matovic 1990; Oris 2000; Van de Putte 2003), and indicate that preferences for marriage partners existed also in terms of occupations and SES, as previously mentioned (see also Dribe and Lundh 2009a). However, it should be noted that, in historical studies, it is difficult to determine whether individual behavior was based on 'true' individual preferences, or was shaped by group norms.

Second, the exposure of individuals to different types of prospective marriage partners influence the number of homogamous and heterogamous marriages. Thus, group size matters; and this factor is now, after years of methodological debate, usually taken into account in studies on homogamy (see, e.g., Kalmijn 1991). However, in addition to group size, other factors also matter, including the degree of openness of the group in question, and the extent of multiple group affiliations among individuals (Blau, Beeker and Fitzpatrick 1984). For example, it is probable that residential location, networks, and exposure to people of different backgrounds in daily and working life affect partner selection and occupational career. Individuals from parental homes characterized by strong occupational identities and household-based production, such as artisans or peasants, might be less exposed to prospective marriage partners of other occupational backgrounds. This is also true for children of higher managers and professionals (see, e.g., De Graaf, Ganzeboom, and Kalmijn 1989; Kalmijn 1994). 
Finally, third parties may affect the marriage choices of young people. For example, in a rural preindustrial society, it is often assumed that partner selection is made strategically in order to maintain or improve income, wealth, social, or occupational status (Dewald 1996; Hurwich 1998; Stone 1977; Stone and Fawtier 1984). These kinds of marriage strategies can be expected to differ between people of different SES. Higher SES groups in preindustrial society, such as farmers, artisans, managers, and professionals, may have formed economic alliances and pooled resources, which were also important for the families involved. One way to do this was through SES homogamy; i.e., by marrying somebody of the same SES origin. In this way, social reproduction could be secured and social welfare in old age indemnified. As previously mentioned, we found strong preferences for homogamy among landholding farmers in our previous study of the same area and period analyzed in this paper (Dribe and Lundh 2005a). However, it should be noted that there were variations in the strength of social identity even within the groups identified here; e.g., between freeholders and tenant farmers or different types of artisans.

According to Swedish law, marriage was a voluntary contract between two individuals. However, parents often intervened in marriage negotiations, and could punish a child financially and socially for choosing the 'wrong' marriage partner. Parental control has been identified by ethnologists as one feature of the marital system of preindustrial rural society, based mainly on studies of landed farmers (Granlund 1969). Contemporary narrators report that farmers sought to marry off their children to their equals; that is to say, within the same social group. Marriage was a financial affair, and wealth and social status were the qualities that were decisive in the choice of marriage partner; much more so than passion or love (see Dribe and Lundh 2009b).

While the strategic approach to marriage for individuals in high SES groups typically aimed at homogamy, the opposite could be expected for lower SES groups. To workers of different sorts, an occupational career required assets, networks, and human capital. One way of getting hold of such resources was through the marriage market; specifically, by marrying a spouse from a higher-status background. Examples include farmhands marrying farmers' daughters or farmers' widows, maids marrying farmers' sons, or apprentices marrying the masters' daughters. Exchange theory provides a specific explanation for the fact that, in some cases, socially heterogamous marriages were formed: in the marriage market, men traded income and professional prestige for female beauty and attractiveness (Schoen and Woolredge 1989; Taylor and Glenn 1976; Udry 1977).

We thus expect SES homogamous marriages to have increased the likelihood of attaining the SES of the parental home. We also expect that SES hypergamy (marrying upwards) was associated with upward intergenerational SES mobility, while SES 
hypogamy (marrying downwards) might have been related to downward intergenerational SES mobility.

In a study of Leuven (Belgium) in the period 1830-1910, Van Bavel, Peeters, and Matthijs (1998) found that intergenerational social mobility (son compared to father) had a positive effect on marital social mobility (groom compared to father-in-law). This causal relationship, in which social mobility took place before marriage and then determined partner choice, may have been present in some urban populations, but was not likely to appear in rural preindustrial northwestern Europe. In rural areas of 19thcentury Sweden, for example, occupations were structured by gender, age/skill, and marital status. Some occupations were reserved for unmarried people, and others for married people. Along with civil status and the occupation came certain housing conditions. In the servant system, most young people worked as farmhands or maids for a certain period of life, usually while waiting to get married (see, e.g., Dribe 2000; Hajnal 1983; Harnesk 1990; Laslett 1977; Mitterauer 1988). After marriage, they took up other occupations, such as farmer, crofter, artisan, or agricultural worker. Unmarried servants usually lived in the master's household; only after getting married could a servant form a separate household. This implies that people were normally registered as male servant (dräng) or female servant (piga) in the marriage registers, but then after some time attained a new status as they took over a farm or acquired proper employment as an artisan, agricultural laborer, etc. (Lundh 1999).

For adults, age is negatively correlated to fecundity, health, and physical working ability. In theory, a young person is therefore a good match in the marriage market, and could be assumed to be able to attract a spouse with the same positive characteristics. In age-homogamous marriages, the husband and wife contribute equal amounts of these assets, and, to the extent that such couples married while they were young, the sum of these assets should exceed the amount of assets held by couples with a larger age difference. Consequently, an age-homogamous marriage should have a positive effect on social attainment later in life. However, in some social and historical contexts, other characteristics were more important than age, and there were indeed social norms steering individual behavior in the marriage market. In studies of historical demography and anthropology, regional patterns of age differences between spouses are often related to cultural or institutional characteristics (Hajnal 1983; Skinner 1997). Age homogamy or heterogamy is thus seen as a consequence of social norms of the proper age at marriage for men and women (Van de Putte et al. 2009; Van Poppel and Nelissen 1999. See also Flandrin 1975; Le Goff and Schmitt 1981; Segalen 1983).

In a Western European, Malthusian context, higher age was also positively linked to the possibility of getting married. Unmarried people worked and saved or waited for a transfer of family property in the form of an inheritance or retirement contract in order to be able to afford a marriage (Schofield 1976). In the latter case, the age gap could be 
assumed to be bigger than in cases where the economic foundation of marriage was wage labor and personal savings. In this context, the age difference between spouses might indicate that they had a better potential for social attainment and mobility. For example, a couple in which the husband was older because he had waited until he had received his inheritance, and the wife was younger and more productive, possessed more assets than other union combinations. Under such circumstances, we would expect age heterogamy to have had a positive influence on social attainment and social mobility. In most of Europe, sons, and especially the eldest son, were favored when properties were passed between generations. Even though Swedish inheritance legislation was quite egalitarian and all siblings inherited, we know that sons were favored both by law and in practice (Dribe and Lundh 2005b, 2005c). Furthermore, while the female life cycle included work as a servant while young, and responsibility for domestic work later, supplemented only occasionally by wage labor outside the household; male working careers were oriented towards productive work as a selfemployed or wage laborer. By investing in human capital accumulation as a farmhand, apprentice, or assistant while still unmarried, men increased the probability of social attainment or advancement later in life. Therefore, to the extent that age heterogamy was important for social attainment and mobility, we would expect age-heterogamous marriages in which the husband was senior to the wife to have had a positive impact on SES attainment and mobility.

Standard economic theories of migration usually assume that migrants are positively selected in terms of ability and productivity (e.g., Chiswick 1978; Sjaastad 1962). Potential migrants make cost-benefit calculations of the net gains of migration, and choose to move if the net gain is positive. More productive individuals, e.g., people who are young, well-educated, and with greater inherent abilities generally have more to gain from migration than others, and are consequently overrepresented among migrants. Therefore, after a period of adaptation to new conditions, migrants often end up in a higher socioeconomic position, earning more than natives. There is some evidence that this positive selection, and the greater degree of social advancement among migrants, also characterized preindustrial society (Long 2005), even though there are studies that find no support for this hypothesis (Stewart 2006). Moreover, the effects of migration on SES attainment and mobility can be expected to differ between different SES groups. Most notably, people of landholding origin can be expected to face higher risks of downward mobility if they move than if they stay because of the importance of inheritance and local networks for this group (see, e.g., Ferrie 1999: Ch. 7; Hersovici 1998).

Most migrants in the area under study were unmarried life-cycle servants, with unskilled agrarian workers dominating among migrating families. By contrast, the proportions of professionals and skilled workers were quite small (e.g., Dribe 2000, 
2003). Nevertheless, we cannot exclude the possibility of positive self-selection in terms of unobserved characteristics among migrants, such as ability and industriousness, even in this context. In such a case, exogamy might well be connected to higher SES attainment and increased opportunities for upward SES mobility.

Discrimination and hostility towards strangers may have been a barrier for social attainment of migrants. As was previously mentioned, studies of city life in 19thcentury Europe report the existence of a hostile mentality in the native population towards strangers and immigrants. Little is known about conditions in rural areas, but such negative attitudes may also have been prevalent there, creating barriers for spatially endogamous marriages, and implying exclusion in general.

Lack of local networks might also have been a problem for social attainment and mobility of migrants and their families. Access to local networks meant opportunities for training, better employment, access to credit, etc. Being born and raised in the area of residence can be expected to have been associated with wider and deeper networks in the place of residence, which may have facilitated attaining higher SES and advancing socially. Similarly, the lack of such networks might well have made it more difficult to maintain SES, and may thus have increased the risks of downward SES mobility. It seems reasonable to expect that geographically exogamous couples had less access to local networks than married couples originating in the parish of residence. The lowest degree of access to networks could be expected for couples in which neither of the spouses were born in the area of residence. Thus, from this perspective, we would expect geographic exogamy to be associated with lower SES attainment and higher risks of downward SES mobility.

Taken together, we expect partner selection to be a crucial part of the process of SES attainment and mobility. In addition to the SES origin of the spouse, the age difference and geographic origin may be expected to be important. For landholding peasants, we expect the marriage strategy of socially homogamous unions to be successful in maintaining the SES status and in avoiding downward social mobility. We also expect SES hypergamy to be associated with higher SES attainment and to better chances of upward SES mobility, while SES hypogamy is likely to be associated with downward mobility and low attainment. From an access-to-networks or xenophobia perspective, we also expect geographically exogamous couples to face higher risks of downward mobility and lower SES attainment. Positive selection of migrants might, however, counteract this negative effect of exogamy. As far as age differences between spouses are concerned, we expect age-homogamous unions and husband-older heterogamous unions to have offered the best prospects of higher SES attainment and mobility. 


\section{Area and data}

The data used are based on continuously maintained population registers (catechetical examination registers) available from the Scanian Demographic Database ${ }^{3}$ for five rural parishes in western Scania in southern Sweden: Hög, Kävlinge, Halmstad, Sireköpinge, and Kågeröd. They are all about 10 kilometers from the coast in the western part of Scania, which is the southernmost province of Sweden. The social structure of these parishes varied somewhat. Hög and Kävlinge were dominated by farmers on freehold and crown land with rather similar social characteristics, while the other three parishes were totally dominated by tenant farmers on manorial land (see Dribe 2000). In addition to the peasant group, the parishes also contained various landless and semi-landless groups who made their living working for other people. In 1830, the five parishes had 3,978 inhabitants. By 1895, that figure had increased to 5,539, representing an average annual increase of $0.5 \%$ during this 65 -year period, or a somewhat slower rate of growth than for rural Sweden as a whole during the same period, which was $0.6 \%$ per year (Statistics Sweden 1999: 42).

Data from the population registers has been linked to family reconstitutions based on vital events from church records, and to poll tax registers, which provide annual information on, for example, size and type of landholding. The database contains all individuals born in the different parishes, or people migrating into them. Each individual is followed from birth or time of arrival in the parish to death or migration out of the parish. For the individuals in the database, there is information on a wide range of demographic, social, and economic variables at the individual, family, and household levels.

Because this study deals with partner selection and SES mobility, we need to have information on the socioeconomic backgrounds of both spouses in a given couple. Due to very high rates of migration in this area (Dribe 2000,2003) restricting the analysis to the population born in the parishes, and for whom information about the conditions in the parental home is readily available, would most likely lead to a selection bias. This is because the sampled couples would have been taken from among non-migrants who, most probably, would therefore have been selected by reference to landholding, physical ability, etc. (see Dribe 2000: ch. 2).

To avoid this problem, we have traced all married individuals back to their birth parish, regardless of whether or not their marriages took place in the parish of residence, and added information about their fathers' SES at the time of their birth. This was done using information about date and place of birth in the registers in order to find the individual in the registers of the parish of birth. Information about the occupations

${ }^{3}$ The Scanian Demographic Database is maintained by the Centre for Economic Demography, Lund University (www.ed.lu.se). 
of fathers has been taken from the birth records-or, if available, the catechetical examination registers - and data on access to land or croft was taken from poll tax registers. We have thus obtained information about the socioeconomic origins of both the husband and his wife without introducing too much selection bias stemming from migration. However, we are unable to link data on the parental home for about $30 \%$ of all individuals in the sample because information about their date and place of birth is either incorrect or missing. In the period 1815-1894, 5,406 married couples were counted in the five parishes under investigation. After selecting the couples observed at the husband's age 45 (or, for out-migrants, the highest age between 35 and 45) 2,804 couples remained. This is the sample used in this study.

Data on occupation is derived from population registers, birth registers (occupation of the father), and marriage registers, while information about the size and type of landholding comes from the poll tax registers. All occupations in the database have been coded into HISCO (Van Leeuwen, Maas, and Miles 2002), and then classified according to HISCLASS (Maas and Van Leeuwen 2005; see also Dribe and Lundh $2009 \mathrm{~b}){ }^{4}$ HISCLASS is a 12-category classification scheme based on skill level, degree of supervision, manual or non-manual, and urban or rural. Creating these kinds of classifications is not a straightforward matter, and it becomes even more complex when the goal is to relate the different groups to concepts such as "class" or "power" (see, e.g., Van de Putte 2006). Despite these concerns, we believe that using this system makes it easier to differentiate the landless group in this largely rural society.

In addition to the occupational information, we also use information on tenure and size of landholding to capture important differences within the farmer category. Because of the rather small sample and rural character of our community, it is not possible to use the full range of the HISCLASS in the analysis. The final classification used is displayed in the table below, and the distributions of socioeconomic attainment and origin in the sample are available in Tables 1 and 2 below.

\footnotetext{
${ }^{4}$ The classification into HISCLASS was made using the recode job: hisco_hisclass12a_@.inc, May 2004, see http://historyofwork.iisg.nl/list pub.php? categories=hisclass.
} 


\section{Socioeconomic classification}

\begin{tabular}{lll}
\hline \multicolumn{1}{c}{ SES } & HISCLASS & Description \\
\hline Higher occupations & $1-6$ & $\begin{array}{l}\text { Higher managers, higher professionals, lower } \\
\text { managers, lower professionals, clerical and sales, } \\
\text { lower clerical and sales, foremen } \\
\geq 1 / 16 \text { mantal }\end{array}$, Freeholders (SK) and Crown tenants \\
Freeholders & 8 & $\begin{array}{l}(\text { KR) } \\
\geq 1 / 16 \text { mantal, tenants on manorial land }\end{array}$ \\
Tenants & 8 & Craftsmen etc. \\
Skilled workers & 7 & $<1 / 16$ mantal, freeholders and tenants \\
Smallholders & 8 & Crofters, low-ranking soldiers, carpenters etc. \\
Lower skilled workers & $9-10$ & Farm workers, other workers, servants, etc. \\
Unskilled workers & $11-12$ &
\end{tabular}

\section{Methods}

We define intergenerational SES mobility by comparing the SES attainment at the husband's age 45 (or the last observation after 35 for those dying or leaving the parish) and the SES of the father of the husband and the wife at the time of their birth. Occupational status at marriage is not a good indicator of final status attained, especially not in this context, because most people were only listed as life-cycle servants in the marriage registers referring to their status prior to marriage. Instead, we use the SES at husband's age 45 as a proxy for the final (highest) SES attained. This means that people who died between marriage and age 35 will not be included in the analysis, but, as mean ages at marriage were close to 30 , and the mortality in these ages was low, this should not bias the results. The main focus of this paper is to look at the impact of different aspects of partner selection (SES, age, place of birth) on SES attainment and mobility. We do this by estimating a series of regression models, including types of marriages as explanatory variables, controlling for SES origin, parish, year of birth, and year of birth squared. We thereby obtain estimates of the effects of different types of partner selections on SES attainment and mobility, given individual characteristics.

When using these kinds of data and models, there are potential causality and endogeneity problems that make it difficult to interpret the effects of variables as causal in a strict sense. However, a previous study based on individual-level longitudinal data

\footnotetext{
${ }^{5}$ Mantal is a rough measure of the productive potential of the farm not directly convertible into an areal measure such as acres. 1/16 of a mantal is used as the limit of subsistence, which is also the way contemporary society defined it (see Dribe $2000, \mathrm{Ch} .2$ for a discussion).
} 
showed that the risk is small of a reversed causality, i.e., that the occupational attainment and social mobility occurred before, rather than after marriage, and thus influenced the choice of marriage partner. The servant system involved all social groups, including landholding peasants, and the majority of teenagers worked as lifecycle servants while unmarried. According to the parish records, with few exceptions (e.g., among managers and professionals, and sometimes among peasants) a son had the occupation of 'farmhand' prior to marriage. The vast majority of the brides and grooms in the marriage records of the area under investigation were described as either son/daughter or farmhand/maid, which indicated their servant status prior to the wedding. After the wedding, when the first child was born, the occupation of the husband that was noted in the parish records was usually one that was typical for married males (Lundh 1999). Since the occupation of servant was only temporary, and was common among all social groups, including landholding peasants, it cannot be considered to be the SES status at marriage. Rather, with marriage, the period of service ended, and the couple established a household with the combination of occupation and dwelling that constituted the real SES status of the household. It was only in rare cases that the groom was established in an adult occupation, and had a dwelling suitable for a family when he was still unmarried.

It may well be the case that some unobserved characteristic (e.g., 'ability') explains both partner selection and SES attainment and mobility. Thus, even in cases where we show some effect of partner selection on SES attainment and mobility, we cannot firmly conclude that partner selection exogenously caused the SES attainment or the intergenerational SES mobility. On the other hand, we will be able to draw conclusions about the relationship between partner selection and SES attainment and mobility. Most likely both partner selection and SES attainment and mobility were parts of the same decision-making process intimately connected to social reproduction between generations, and thus it is difficult to view them in isolation.

We model SES attainment using an ordered logit model, where the SES groups are ordered as in the table above. The advantage of using this method of modeling attainment is that it allows us to model all outcomes simultaneously. However, it should be noted that this model assumes that SES groups can be ordered, and in cases where this assumption cannot be upheld, the model can produce strange results. We believe that the SES classification used is ordered, even though there are some uncertainties in the middle of the classification. It seems unproblematic that the higher occupations are ordered above freeholders, and that freeholders in turn are above tenants and skilled workers. It is also clear that unskilled workers are below the lower skilled, and that this group in turn are below the other groups. It is more difficult, however, to judge the order of smallholders and skilled workers. To check the robustness of the results, we compare them with logit estimates of each SES attainment separately. 
Intergenerational SES mobility is modeled using a multinomial logit model, with upward and downward mobility as the competing outcomes, and with no mobility as the base outcome. To allow full mobility, the highest and lowest SES groups are excluded from the sample. To check if this exclusion affects the results in any way, we also compare with separate logit models for upward (excluding highest SES) and downward (excluding lowest SES) mobility.

The explanatory variables of main interest are those related to partner selection. SES homogamy is defined as couples in which both spouses originate in the same SES groups according to the above classification. Hypergamy is defined as marrying a spouse from a higher SES origin, and hypogamy is defined as marrying a spouse from a lower SES group. Age homogamy is said to exist when spouses are within three years of age of each other. This choice of age boundary is somewhat arbitrary, but we want to keep the homogamous category rather broad, because it increases the likelihood of identifying potential patterns in heterogamy, which might be lost if too much of the normal variation is included in the heterogamous category. We also distinguish husband-older heterogamy (i.e., the husband more than three years older than his wife) from wife-older heterogamy (i.e., the wife more than three years older than her husband). Finally, geographic endogamous couples are those in which both spouses were born in the parish of residence or in one of the neighboring parishes. For exogamy, we distinguish between couples in which only the husband was born outside the area (parish of residence and neighboring parishes), only the wife was born outside, and both the husband and the wife originated outside the area.

In addition to the partner selection variables, we also control for the SES origin of the individual, year of birth, year of birth squared, and parish of residence. The latter is included to capture differences between the parishes not accounted for by the other covariates in the model.

Thus, we model the impact of SES homogamy, age homogamy, and geographic endogamy, while controlling for individual origin in terms of SES. This means that we are not primarily interested in the impact of the individual's own inherited resources in terms of SES, but in what could be gained in addition to these assets by marrying homogamously or heterogamously. This provides at least a rough indication of the importance of partner selection for SES attainment and mobility.

\section{Results}

Table 1 displays the distributions of couple-specific covariates. About half of the sample belonged to the lower-skilled and unskilled workers, while about one-quarter belonged to the higher occupations and landed farmers. About $35 \%$ of the couples were 
age homogamous (i.e., husband and wife were within three years of age of each other), while $50 \%$ were husband-older heterogamous, and $15 \%$ were wife-older heterogamous. Thus it was found to be much more common that the husband was older than the wife was older. It should be noted that we analyze all marriages, not only first marriages, which naturally implies a high proportion of age-heterogamous marriages. Turning to geographic endogamy, we find that a large majority of marriages were exogamous, i.e., at least one spouse originated outside the investigation area and the neighboring parishes. This shows the high degree of geographic mobility of the time, even though most moves were short range (see also Dribe 2003).

\section{Table 1: Distributions of couple-specific covariates in the sample}

\begin{tabular}{lr}
\hline & $\%$ \\
\hline SES at husband's age 45 & \\
Higher occ. & 6.8 \\
Freeholders & 7.2 \\
Tenants & 10.0 \\
Skilled & 7.1 \\
Semi-landless & 16.2 \\
Lower skilled & 20.9 \\
Unskilled & 27.9 \\
NA & 4.1 \\
Total & 100.0 \\
Age homogamy & \\
Homogamous & 35.5 \\
Husband 3 + older & 49.9 \\
Wife 3+ older & 14.6 \\
Total & 100.0 \\
Geographic endogamy & \\
Endogamous & 35.2 \\
Exogamous, husband outside & 17.9 \\
Exogamous, wife outside & 17.3 \\
Exogamous, both outside & 29.6 \\
Total & 100.0 \\
Parish & 10.1 \\
Hög & 13.0 \\
Kävlinge & 19.6 \\
Halmstad & 25.3 \\
Sireköpinge & 32.0 \\
Kågeröd & $\mathbf{2 8 0 4}$ \\
\hline Total & \\
\hline N & \\
\hline
\end{tabular}

Source: The Scanian Demographic Database, Centre for Economic Demography, Lund University. 
Table 2: Distribution of individual-specific covariates for partners in the couples

\begin{tabular}{lrr}
\hline & Husbands & Wives \\
\hline SES at birth & & 3.1 \\
Higher occ. & 9.4 & 10.6 \\
Freeholders & 18.9 & 19.0 \\
Tenants & 3.0 & 3.3 \\
Skilled & 6.3 & 6.1 \\
Semi-landless & 22.5 & 20.5 \\
Lower skilled & 6.6 & 7.4 \\
Unskilled & 30.2 & 30.1 \\
NA & 100.0 & 100.0 \\
Total & & \\
SES homogamy & 19.5 & 19.5 \\
Homogamous & 18.4 & 17.1 \\
Hypergamous & 17.1 & 18.4 \\
Hypogamous & 45.0 & 45.0 \\
NA & 100.0 & 100.0 \\
Total & & \\
Intergenerational SES mobility & 21.1 & 19.8 \\
No mobility & 16.8 & 16.4 \\
Upward & 29.1 & 31.2 \\
Downward & 33.0 & 32.7 \\
NA & 100.0 & 100.0 \\
Total & 1821.3 & 1824.4 \\
Year of birth & $\mathbf{2 8 0 4}$ & $\mathbf{2 8 0 4}$ \\
\hline N & &
\end{tabular}

Source: See Table 1.

For SES homogamy (Table 2), we lack information on socioeconomic background for about $45 \%$ of the sample. Looking only at the couples for whom we have this information, we find that about $35 \%$ were homogamous, $33 \%$ of the men and $31 \%$ of the women were hypergamous (i.e., married to someone from a higher SES origin), and $31 \%$ of men and $33 \%$ of women were hypogamous (i.e., married to someone from a lower SES origin).

About $30 \%$ of the individuals for whom we have information both on SES origin and SES attainment were immobile, i.e., the achieved the same SES as their fathers. Downward mobility was about twice as frequent as upward mobility (c. $45 \%$ vs. c. 
$25 \%$ ). This is also evident when comparing the socioeconomic structure at birth and at the husband's age 45 in Tables 1 and 2. The proportions of the sample belonging in the lower segments of the socioeconomic scale were considerably higher at age 45 than at birth.

Table 3 displays the ordered logit estimates of SES attainment at husband's age 45 . It is difficult to interpret the magnitude of effects or the effects on different outcomes directly from the coefficients. Nevertheless, they tell us something about the broader associations between the explanatory variables and socioeconomic attainment. Since a higher SES score implies lower socioeconomic status (with higher occupations coded as 1, and unskilled as 7), a negative estimate indicates a lower probability of reaching a lower SES, while a positive estimate indicates a higher probability of reaching a lower SES, compared to the reference category.

Looking first at SES at birth, it seems clear that the socioeconomic status of the parental home (i.e., of the father) had a powerful impact on SES attainment. Being of higher occupational origin made it less likely that an individual would end up in a lower SES group than if he or she were of freeholder origin. However, tenants, skilled workers, and smallholders showed higher probabilities of attaining lower SES than individuals of freeholder origin. The magnitudes of the effects are also similar in these groups, as workers of lower skilled and unskilled origins had even higher probabilities of low SES attainment.

We now turn to our main focus: the effects of the homogamy variables. Being married to someone of a higher SES origin, or hypergamy, implied a lower risk of reaching a low SES relative to the homogamously married reference category (only statistically significant at the $10 \%$ level for men). Being married to someone from a lower SES, or hypogamy, increased the risk of ending up in a lower SES relative to those homogamously married. It also seems that people who married without information about the spouse's SES origin were in marriages that resembled hypogamous unions more than either hypergamous or homogamous marriages. 
Table 3: Ordered logit estimates of SES at husband's age 45

\begin{tabular}{|c|c|c|c|c|}
\hline & \multicolumn{2}{|c|}{ Husbands } & \multicolumn{2}{|c|}{ Wives } \\
\hline & Coef. & $P>|z|$ & Coef. & $\mathrm{P}>|\mathrm{z}|$ \\
\hline \multicolumn{5}{|l|}{ SES at birth } \\
\hline Higher occupations & -0.578 & 0.014 & -0.399 & 0.080 \\
\hline Freeholders & ref & & ref & \\
\hline Tenants & 0.548 & 0.000 & 0.951 & 0.000 \\
\hline Skilled & 0.433 & 0.051 & 0.878 & 0.000 \\
\hline Semi-landless & 0.544 & 0.003 & 0.935 & 0.000 \\
\hline Lower skilled & 1.676 & 0.000 & 1.919 & 0.000 \\
\hline Unskilled & 1.961 & 0.000 & 2.477 & 0.000 \\
\hline NA & 1.157 & 0.000 & 1.554 & 0.000 \\
\hline \multicolumn{5}{|l|}{ SES homogamy } \\
\hline Homogamous & ref & & ref & \\
\hline Hypergamous & -0.196 & 0.096 & -0.413 & 0.001 \\
\hline Hypogamous & 0.644 & 0.000 & 0.792 & 0.000 \\
\hline NA & 0.419 & 0.001 & 0.378 & 0.002 \\
\hline \multicolumn{5}{|l|}{ Age homogamy } \\
\hline Homogamous & ref & & ref & \\
\hline Husband 3 + older & -0.133 & 0.079 & -0.199 & 0.009 \\
\hline Wife $3+$ older & 0.207 & 0.054 & 0.289 & 0.008 \\
\hline \multicolumn{5}{|l|}{ Geographical endogamy } \\
\hline Endogamous & ref & & ref & \\
\hline Exogamous, hu. Outside & 0.014 & 0.893 & 0.141 & 0.170 \\
\hline Exogamous, wi. Outside & 0.138 & 0.184 & 0.182 & 0.083 \\
\hline Exogamous, both outside & -0.149 & 0.124 & -0.084 & 0.385 \\
\hline Year of birth & 0.073 & 0.492 & 0.222 & 0.021 \\
\hline Year of birth sq. & 0.000 & 0.539 & 0.000 & 0.025 \\
\hline \multicolumn{5}{|l|}{ Parish } \\
\hline Hög & ref & & ref & \\
\hline Kävlinge & 0.084 & 0.554 & 0.045 & 0.749 \\
\hline Halmstad & 0.691 & 0.000 & 0.623 & 0.000 \\
\hline Sireköpinge & 0.540 & 0.000 & 0.496 & 0.000 \\
\hline Kågeröd & 0.442 & 0.001 & 0.376 & 0.003 \\
\hline $\mathbf{N}$ & 2690 & & 2690 & \\
\hline LR chi2 & 425.7 & & 475.5 & \\
\hline Prob > chi2 & 0.000 & & 0.000 & \\
\hline
\end{tabular}

Source: See Table 1. 
Husband-older heterogamy implied a lower risk of low SES attainment relative to age-homogamous marriages (statistically significant for men only at the $8 \%$ level). Wife-older heterogamy implied a higher risk of lower SES attainment than for agehomogamous marriages. There were no statistically significant effects of geographic exogamy, with the possible exception of a positive effect of wife-outside exogamy for women ( $p=0.08$ ). Thus, to the extent that exogamy affected SES attainment, it seems to have increased the risk of low-status attainment.

As already mentioned, the raw ordered logit estimates only allow for broad interpretations of basic differences and directions of effects. To get a more detailed picture, we calculated the marginal effects on the predicted probabilities (calculated at means of covariates) of each SES attainment. Table 4 displays these marginal effects of SES origin and the homogamy variables, which are the main focus of attention here. The calculations are based on the model in Table 3, controlling for all covariates.

Compared to SES homogamy, hypogamous marriages entailed a lower probability of ending up in middle and higher SES groups (smallholders and higher), but increased the probability of lower SES attainment (lower-skilled and unskilled workers). Hypergamy, on the other hand, increased the chances of reaching middle and higher SES groups, but lowered the chances of low SES attainment. The direction of the effects was highly similar between men and women, but the effects of hypergamy were sometimes not statistically significant for men, while they were always statistically significant for women. The magnitudes of the effects were also quite sizable in several cases. For example, being hypogamously married lowered the probability of entering the highest group for men by 2.8 percentage points relative to the homogamously married, which should be compared to an overall predicted probability of attaining this status of $5.4 \%$. Thus, the difference between hypogamy and homogamy in this case amounted to something like half the predicted probability of attaining higher occupations. Similarly, the chances that hypogamous men would end up in the lowest SES category were 13.7 percentage points higher than they were for homogamous men, and the overall predicted probability of attaining this SES group was $26.8 \%$. 
Table 4: Marginal effects on SES attainment at husband's age 45. Based on ordered logit estimates

\section{A. Husbands}

\begin{tabular}{|c|c|c|c|c|c|c|c|c|}
\hline & \multicolumn{2}{|c|}{ Higher occ. } & \multicolumn{2}{|c|}{ Freeholders } & \multicolumn{2}{|c|}{ Tenants } & \multicolumn{2}{|c|}{ Skilled workers } \\
\hline & $\mathrm{dy} / \mathrm{dx}$ & $\mathrm{P}>|\mathrm{z}|$ & $\mathrm{dy} / \mathrm{dx}$ & $\mathrm{P}>|\mathrm{z}|$ & $\mathrm{dy} / \mathrm{dx}$ & $\mathrm{P}>|\mathrm{z}|$ & $\mathrm{dy} / \mathrm{dx}$ & $\mathrm{P}>|\mathrm{z}|$ \\
\hline Pred.probability & 0.054 & & 0.066 & & 0.106 & & 0.080 & \\
\hline \multicolumn{9}{|l|}{ SES at birth } \\
\hline Higher occupations & 0.038 & 0.051 & 0.037 & 0.033 & 0.041 & 0.012 & 0.018 & 0.001 \\
\hline Freeholders & ref & & ref & & ref & & ref & \\
\hline Tenants & -0.024 & 0.000 & -0.027 & 0.000 & -0.036 & 0.000 & -0.021 & 0.001 \\
\hline Skilled & -0.018 & 0.019 & -0.021 & 0.025 & -0.028 & 0.036 & -0.017 & 0.056 \\
\hline Semi-landless & -0.023 & 0.000 & -0.025 & 0.001 & -0.035 & 0.001 & -0.021 & 0.004 \\
\hline Lower skilled & -0.061 & 0.000 & -0.068 & 0.000 & -0.095 & 0.000 & -0.059 & 0.000 \\
\hline Unskilled & -0.052 & 0.000 & -0.061 & 0.000 & -0.092 & 0.000 & -0.064 & 0.000 \\
\hline NA & -0.050 & 0.000 & -0.054 & 0.000 & -0.073 & 0.000 & -0.043 & 0.000 \\
\hline \multicolumn{9}{|l|}{ SES homogamy } \\
\hline Homogamous & ref & & ref & & ref & & ref & \\
\hline Hypergamous & 0.011 & 0.118 & 0.011 & 0.111 & 0.014 & 0.100 & 0.007 & 0.088 \\
\hline Hypogamous & -0.028 & 0.000 & -0.030 & 0.000 & -0.042 & 0.000 & -0.025 & 0.000 \\
\hline NA & -0.021 & 0.001 & -0.022 & 0.001 & -0.029 & 0.001 & -0.016 & 0.001 \\
\hline \multicolumn{9}{|l|}{ Age homogamy } \\
\hline Homogamous & ref & & ref & & ref & & ref & \\
\hline Husband $3+$ older & 0.007 & 0.081 & 0.007 & 0.081 & 0.009 & 0.080 & 0.005 & 0.081 \\
\hline Wife $3+$ older & -0.010 & 0.042 & -0.011 & 0.045 & -0.014 & 0.051 & -0.008 & 0.061 \\
\hline \multicolumn{9}{|l|}{$\begin{array}{l}\text { Geographical } \\
\text { endogamy }\end{array}$} \\
\hline Endogamous & ref & & ref & & ref & & ref & \\
\hline $\begin{array}{l}\text { Exogamous, hu. } \\
\text { outside }\end{array}$ & -0.001 & 0.892 & -0.001 & 0.892 & -0.001 & 0.893 & -0.001 & 0.893 \\
\hline $\begin{array}{l}\text { Exogamous, wi. } \\
\text { outside }\end{array}$ & -0.007 & 0.167 & -0.007 & 0.172 & -0.009 & 0.179 & -0.005 & 0.191 \\
\hline $\begin{array}{l}\text { Exogamous, both } \\
\text { outside }\end{array}$ & 0.008 & 0.137 & 0.008 & 0.134 & 0.010 & 0.128 & 0.006 & 0.121 \\
\hline
\end{tabular}


Dribe \& Lundh: Marriage choices and social reproduction

Table 4: (Continued)

A. Husbands

\begin{tabular}{|c|c|c|c|c|c|c|c|c|}
\hline & \multicolumn{2}{|c|}{ Semi-landless } & \multicolumn{2}{|c|}{ Lower skilled w. } & \multicolumn{2}{|c|}{ Unskilled work. } & \multicolumn{2}{|c|}{ Semi-landless } \\
\hline & $\mathrm{dy} / \mathrm{dx}$ & $\mathrm{P}>|\mathrm{z}|$ & $\mathrm{dy} / \mathrm{dx}$ & $\mathrm{dy} / \mathrm{dx}$ & $\mathrm{P}>|\mathrm{z}|$ & $\mathrm{dy} / \mathrm{dx}$ & $\mathrm{dy} / \mathrm{dx}$ & $\mathrm{P}>|\mathrm{z}|$ \\
\hline Pred.probability & 0.189 & & 0.237 & 0.189 & & 0.237 & 0.189 & \\
\hline \multicolumn{9}{|l|}{ SES at birth } \\
\hline Higher occupations & 0.008 & 0.022 & -0.043 & 0.008 & 0.022 & -0.043 & 0.008 & 0.022 \\
\hline Freeholders & ref & & ref & ref & & ref & ref & \\
\hline Tenants & -0.027 & 0.002 & 0.020 & -0.027 & 0.002 & 0.020 & -0.027 & 0.002 \\
\hline Skilled & -0.022 & 0.112 & 0.014 & -0.022 & 0.112 & 0.014 & -0.022 & 0.112 \\
\hline Semi-landless & -0.029 & 0.018 & 0.015 & -0.029 & 0.018 & 0.015 & -0.029 & 0.018 \\
\hline Lower skilled & -0.093 & 0.000 & 0.005 & -0.093 & 0.000 & 0.005 & -0.093 & 0.000 \\
\hline Unskilled & -0.123 & 0.000 & -0.061 & -0.123 & 0.000 & -0.061 & -0.123 & 0.000 \\
\hline NA & -0.057 & 0.000 & 0.032 & -0.057 & 0.000 & 0.032 & -0.057 & 0.000 \\
\hline \multicolumn{9}{|l|}{ SES homogamy } \\
\hline Homogamous & ref & & ref & ref & & ref & ref & \\
\hline Hypergamous & 0.006 & 0.053 & -0.012 & 0.006 & 0.053 & -0.012 & 0.006 & 0.053 \\
\hline Hypogamous & -0.033 & 0.000 & 0.020 & -0.033 & 0.000 & 0.020 & -0.033 & 0.000 \\
\hline NA & -0.016 & 0.001 & 0.021 & -0.016 & 0.001 & 0.021 & -0.016 & 0.001 \\
\hline \multicolumn{9}{|l|}{ Age homogamy } \\
\hline Homogamous & ref & & ref & ref & & ref & ref & \\
\hline Husband $3+$ older & 0.005 & 0.082 & -0.007 & 0.005 & 0.082 & -0.007 & 0.005 & 0.082 \\
\hline Wife $3+$ older & -0.009 & 0.090 & 0.010 & -0.009 & 0.090 & 0.010 & -0.009 & 0.090 \\
\hline \multicolumn{9}{|l|}{$\begin{array}{l}\text { Geographical } \\
\text { endogamy }\end{array}$} \\
\hline Endogamous & ref & & ref & ref & & ref & ref & \\
\hline $\begin{array}{l}\text { Exogamous, hu. } \\
\text { outside }\end{array}$ & -0.001 & 0.894 & 0.001 & -0.001 & 0.894 & 0.001 & -0.001 & 0.894 \\
\hline $\begin{array}{l}\text { Exogamous, wi. } \\
\text { outside }\end{array}$ & -0.006 & 0.222 & 0.007 & -0.006 & 0.222 & 0.007 & -0.006 & 0.222 \\
\hline $\begin{array}{l}\text { Exogamous, both } \\
\text { outside }\end{array}$ & 0.005 & 0.100 & -0.008 & 0.005 & 0.100 & -0.008 & 0.005 & 0.100 \\
\hline
\end{tabular}


Table 4: $\quad$ (Continued)

B. Wives

\begin{tabular}{|c|c|c|c|c|c|c|c|c|}
\hline & \multicolumn{2}{|c|}{ Higher occ. } & \multicolumn{2}{|c|}{ Freeholders } & \multicolumn{2}{|c|}{ Tenants } & \multicolumn{2}{|c|}{ Skilled workers } \\
\hline & $\mathrm{dy} / \mathrm{dx}$ & $\mathrm{P}>|\mathrm{z}|$ & $\mathrm{dy} / \mathrm{dx}$ & $\mathrm{P}>|\mathrm{z}|$ & $\mathrm{dy} / \mathrm{dx}$ & $\mathrm{P}>|\mathrm{z}|$ & $\mathrm{dy} / \mathrm{dx}$ & $\mathrm{P}>|\mathrm{z}|$ \\
\hline Pred.probability & 0.052 & & 0.065 & & 0.106 & & 0.080 & \\
\hline \multicolumn{9}{|l|}{ SES at birth } \\
\hline Higher occupations & 0.023 & 0.136 & 0.024 & 0.115 & 0.029 & 0.083 & 0.014 & 0.044 \\
\hline Freeholders & ref & & ref & & ref & & ref & \\
\hline Tenants & -0.037 & 0.000 & -0.042 & 0.000 & -0.059 & 0.000 & -0.036 & 0.000 \\
\hline Skilled & -0.031 & 0.000 & -0.036 & 0.000 & -0.052 & 0.000 & -0.034 & 0.000 \\
\hline Semi-landless & -0.033 & 0.000 & -0.038 & 0.000 & -0.056 & 0.000 & -0.036 & 0.000 \\
\hline Lower skilled & -0.063 & 0.000 & -0.072 & 0.000 & -0.103 & 0.000 & -0.066 & 0.000 \\
\hline Unskilled & -0.056 & 0.000 & -0.068 & 0.000 & -0.104 & 0.000 & -0.072 & 0.000 \\
\hline NA & -0.062 & 0.000 & -0.069 & 0.000 & -0.094 & 0.000 & -0.056 & 0.000 \\
\hline \multicolumn{9}{|l|}{ SES homogamy } \\
\hline Homogamous & ref & & ref & & ref & & ref & \\
\hline Hypergamous & 0.023 & 0.004 & 0.024 & 0.002 & 0.029 & 0.001 & 0.015 & 0.000 \\
\hline Hypogamous & -0.032 & 0.000 & -0.036 & 0.000 & -0.051 & 0.000 & -0.030 & 0.000 \\
\hline NA & -0.018 & 0.002 & -0.020 & 0.002 & -0.026 & 0.002 & -0.014 & 0.003 \\
\hline \multicolumn{9}{|l|}{ Age homogamy } \\
\hline Homogamous & ref & & ref & & ref & & ref & \\
\hline Husband $3+$ older & 0.010 & 0.010 & 0.011 & 0.010 & 0.014 & 0.009 & 0.007 & 0.010 \\
\hline Wife $3+$ older & -0.013 & 0.004 & -0.015 & 0.005 & -0.020 & 0.007 & -0.011 & 0.011 \\
\hline \multicolumn{9}{|l|}{$\begin{array}{l}\text { Geographical } \\
\text { endogamy }\end{array}$} \\
\hline Endogamous & ref & & ref & & ref & & ref & \\
\hline $\begin{array}{l}\text { Exogamous, hu. } \\
\text { outside }\end{array}$ & -0.007 & 0.154 & -0.007 & 0.158 & -0.010 & 0.165 & -0.005 & 0.177 \\
\hline $\begin{array}{l}\text { Exogamous, wi. } \\
\text { outside }\end{array}$ & -0.009 & 0.069 & -0.009 & 0.073 & -0.013 & 0.079 & -0.007 & 0.090 \\
\hline $\begin{array}{l}\text { Exogamous, both } \\
\text { outside }\end{array}$ & 0.004 & 0.394 & 0.005 & 0.392 & 0.006 & 0.388 & 0.003 & 0.383 \\
\hline
\end{tabular}


Dribe \& Lundh: Marriage choices and social reproduction

Table 4: (Continued)

B. Wives

\begin{tabular}{|c|c|c|c|c|c|c|c|c|}
\hline & \multicolumn{2}{|c|}{ Semi-landless } & \multicolumn{2}{|c|}{ Lower skilled w. } & \multicolumn{2}{|c|}{ Unskilled work. } & \multicolumn{2}{|c|}{ Semi-landless } \\
\hline & $\mathrm{dy} / \mathrm{dx}$ & $\mathrm{P}>|\mathrm{z}|$ & $\mathrm{dy} / \mathrm{dx}$ & $\mathrm{dy} / \mathrm{dx}$ & $P>|z|$ & $\mathrm{dy} / \mathrm{dx}$ & $\mathrm{dy} / \mathrm{dx}$ & $\mathrm{P}>|\mathrm{z}|$ \\
\hline Pred.probability & 0.190 & & 0.241 & 0.190 & & 0.241 & 0.190 & \\
\hline \multicolumn{9}{|l|}{ SES at birth } \\
\hline Higher occupations & 0.009 & 0.000 & -0.028 & 0.009 & 0.000 & -0.028 & 0.009 & 0.000 \\
\hline Freeholders & ref & & ref & ref & & ref & ref & \\
\hline Tenants & -0.053 & 0.000 & 0.021 & -0.053 & 0.000 & 0.021 & -0.053 & 0.000 \\
\hline Skilled & -0.054 & 0.001 & 0.008 & -0.054 & 0.001 & 0.008 & -0.054 & 0.001 \\
\hline Semi-landless & -0.057 & 0.000 & 0.008 & -0.057 & 0.000 & 0.008 & -0.057 & 0.000 \\
\hline Lower skilled & -0.111 & 0.000 & -0.014 & -0.111 & 0.000 & -0.014 & -0.111 & 0.000 \\
\hline Unskilled & -0.149 & 0.000 & -0.102 & -0.149 & 0.000 & -0.102 & -0.149 & 0.000 \\
\hline NA & -0.080 & 0.000 & 0.027 & -0.080 & 0.000 & 0.027 & -0.080 & 0.000 \\
\hline \multicolumn{9}{|l|}{ SES homogamy } \\
\hline Homogamous & ref & & ref & ref & & ref & ref & \\
\hline Hypergamous & 0.011 & 0.000 & -0.027 & 0.011 & 0.000 & -0.027 & 0.011 & 0.000 \\
\hline Hypogamous & -0.043 & 0.000 & 0.021 & -0.043 & 0.000 & 0.021 & -0.043 & 0.000 \\
\hline NA & -0.015 & 0.004 & 0.020 & -0.015 & 0.004 & 0.020 & -0.015 & 0.004 \\
\hline \multicolumn{9}{|l|}{ Age homogamy } \\
\hline Homogamous & ref & & ref & ref & & ref & ref & \\
\hline Husband $3+$ older & 0.008 & 0.011 & -0.011 & 0.008 & 0.011 & -0.011 & 0.008 & 0.011 \\
\hline Wife $3+$ older & -0.013 & 0.024 & 0.013 & -0.013 & 0.024 & 0.013 & -0.013 & 0.024 \\
\hline \multicolumn{9}{|l|}{$\begin{array}{l}\text { Geographical } \\
\text { endogamy }\end{array}$} \\
\hline Endogamous & ref & & ref & ref & & ref & ref & \\
\hline $\begin{array}{l}\text { Exogamous, hu. } \\
\text { outside }\end{array}$ & -0.006 & 0.207 & 0.007 & -0.006 & 0.207 & 0.007 & -0.006 & 0.207 \\
\hline $\begin{array}{l}\text { Exogamous, wi. } \\
\text { outside }\end{array}$ & -0.008 & 0.118 & 0.009 & -0.008 & 0.118 & 0.009 & -0.008 & 0.118 \\
\hline $\begin{array}{l}\text { Exogamous, both } \\
\text { outside }\end{array}$ & 0.003 & 0.367 & -0.005 & 0.003 & 0.367 & -0.005 & 0.003 & 0.367 \\
\hline
\end{tabular}

Note: Model also controls for parish, year of birth and year of birth squared. 
Turning to age homogamy, husband-older heterogamy among men was found to be related to higher probabilities of attaining middle and higher statuses, and to lower probabilities of reaching the lower statuses $(\mathrm{p}=0.08)$. The effects were, however, not as large as for SES heterogamy. For women, the corresponding effects were somewhat stronger and also statistically significant. For wife-older heterogamy, the picture was the reverse. Compared to age-homogamous marriages, wife-older marriages showed a lower probability of attaining the higher SES, and a higher probability of reaching the lowest SES. The effects were, however, generally weaker than for SES heterogamy.

Finally, the effects of geographic exogamy on SES attainment were in most cases found to be small and not statistically significant, which further supports the conclusion that exogamy was not of major importance for SES attainment. One exception was exogamously married women born outside the area (i.e., women being married to a husband from the area). For this type of marriage, the effects were negative for higher SES and positive for lower SES, indicating lower SES attainment for these women than for endogamously married women.

The ordered logit estimation assumes that statuses can be ordered. We believe this to be at least roughly true in this case. Nonetheless, results were compared to separate logit estimates for each attainment versus all other attainments, and this generated highly similar results. As could be expected, the difference was for the middle groups (skilled workers and smallholders), where the predicted marginal effects sometimes differed from the separate logit estimates (results not shown).

The results thus far show a quite powerful association between partner selection and socioeconomic status attainment. SES heterogamy appears to have mattered more than age heterogamy, while geographic exogamy seems to have had only a limited impact on SES attainment. Controlling for one's own SES origin, hypergamy - i.e. marrying a spouse of a higher SES origin - helped in attaining higher SES, and this was true for both men and women. Similarly, husband-older heterogamy improved SES attainment relative to being married age-homogamously, while wife-older heterogamy had the opposite effect, lowering SES attainment.

We now turn from SES attainment to intergenerational SES mobility. Table 5 shows marginal effects from the multinomial logit models of SES origin and the different homogamy variables on the probability of intergenerational SES mobility upwards and downwards (models also control for parish, year of birth, and year of birth squared). 
Dribe \& Lundh: Marriage choices and social reproduction

Table 5: Marginal effects of multinomial logit estimates of social mobility (higest and lowest SES excluded)

\begin{tabular}{|c|c|c|c|c|c|c|c|c|}
\hline & \multicolumn{4}{|c|}{ Men } & \multicolumn{4}{|c|}{ Women } \\
\hline & \multicolumn{2}{|c|}{ Upward } & \multicolumn{2}{|c|}{ Downward } & \multicolumn{2}{|c|}{ Upward } & \multicolumn{2}{|c|}{ Downward } \\
\hline & $d y / d x$ & $\mathrm{P}>|\mathrm{z}|$ & $\mathrm{dy} / \mathrm{dx}$ & $\mathrm{P}>|\mathrm{z}|$ & $d y / d x$ & $\mathrm{P}>|z|$ & $\mathrm{dy} / \mathrm{dx}$ & $\mathrm{P}>|\mathrm{z}|$ \\
\hline Pred.probability & 0.195 & & 0.493 & & 0.181 & & 0.543 & \\
\hline \multicolumn{9}{|l|}{ SES at birth } \\
\hline Freeholders & ref & & ref & & ref & & Ref & \\
\hline Tenants & 0.107 & 0.033 & -0.016 & 0.749 & -0.019 & 0.620 & 0.116 & 0.012 \\
\hline Skilled & 0.093 & 0.265 & -0.191 & 0.002 & 0.084 & 0.201 & -0.015 & 0.825 \\
\hline \multirow[t]{2}{*}{ Semi-landless } & 0.349 & 0.000 & -0.315 & 0.000 & 0.171 & 0.004 & -0.232 & 0.000 \\
\hline & 0.296 & 0.000 & -0.245 & 0.000 & 0.210 & 0.000 & -0.189 & 0.000 \\
\hline \multicolumn{9}{|l|}{ SES homogamy } \\
\hline Homogamous & ref & & ref & & ref & & Ref & \\
\hline Hypergamous & 0.123 & 0.000 & -0.057 & 0.142 & 0.151 & 0.000 & -0.046 & 0.284 \\
\hline Hypogamous & -0.073 & 0.009 & 0.197 & 0.000 & -0.114 & 0.000 & 0.267 & 0.000 \\
\hline NA & 0.011 & 0.720 & 0.120 & 0.001 & -0.054 & 0.034 & 0.140 & 0.000 \\
\hline \multicolumn{9}{|l|}{ Age homogamy } \\
\hline Homogamous & ref & & ref & & ref & & Ref & \\
\hline Husband $3+$ older & 0.017 & 0.443 & 0.008 & 0.785 & -0.019 & 0.369 & -0.044 & 0.138 \\
\hline Wife $3+$ older & -0.028 & 0.354 & 0.103 & 0.013 & -0.035 & 0.255 & 0.131 & 0.002 \\
\hline \multicolumn{9}{|l|}{$\begin{array}{l}\text { Geographical } \\
\text { endogamy }\end{array}$} \\
\hline Endogamous & ref & & ref & & ref & & Ref & \\
\hline $\begin{array}{l}\text { Exogamous, hu. } \\
\text { outside }\end{array}$ & -0.013 & 0.663 & 0.113 & 0.007 & 0.012 & 0.692 & 0.086 & 0.030 \\
\hline $\begin{array}{l}\text { Exogamous, wi. } \\
\text { outside }\end{array}$ & -0.027 & 0.352 & 0.109 & 0.005 & 0.002 & 0.951 & 0.137 & 0.001 \\
\hline $\begin{array}{l}\text { Exogamous, both } \\
\text { outside }\end{array}$ & 0.063 & 0.038 & 0.075 & 0.047 & 0.068 & 0.030 & 0.120 & 0.002 \\
\hline N & & 1622 & & & & 1605 & & \\
\hline LR chi2 & & 412.2 & & & & 514.9 & & \\
\hline Prob $>$ chi2 & & 0.000 & & & & 0.000 & & \\
\hline
\end{tabular}

Note: Model also controls for parish, year of birth and year of birth squared.

Source: See Table 1. 
Looking first at partner selection by SES, it seems quite clear that it affected the chances of social mobility a great deal. Hypergamous marriages increased the probability of upward mobility for both men and women, while the effect on downward mobility was negative, but not statistically significant. Hypogamous marriages, on the other hand, lowered the probability of upward SES mobility and increased the risk of downward mobility. All effects were statistically significant, and were also somewhat stronger for women than for men. Thus, as was expected, hypergamy was connected to upward SES mobility, while hypogamy was connected to downward SES mobility. Similar findings have also been made for occupational mobility (Dribe and Lundh 2009b), and for social mobility using a cruder social classification (Dribe and Svensson 2008). The effects were also quite sizable. Hypergamous marriages increased the probability of upward SES mobility by 12 percentage points for men, and almost 15 percentage points for women compared to homogamous marriages, which should be related to an overall predicted probability of upward mobility of about $20 \%$. The effects on downward mobility were also of considerable magnitude, but, relatively speaking, hypergamy seems to have been more important for upward mobility than hypogamy was for downward mobility. Or, to put it differently, to advance socially, finding a partner of higher SES origin was of crucial importance, while downward mobility did not require marrying downwards.

The only statistically significant effects of age homogamy were the higher probabilities of downward mobility for wife-older heterogamous marriages. The effects were quite substantial - about 10 percentage points for men and 13 percentage points for women - but still not as large as for SES heterogamy. Thus, it seems that, in terms of SES mobility, it did not matter whether an individual married homogamously or husband-older heterogamously. In relation to this result, it should be noted that marriages in which the husband was older because he had waited for a transfer of family property were the result of a strategy aiming at maintaining the socioeconomic status, not at increasing it. However, from Table 5 it is clear that both men and women in wife-older heterogamous marriages had higher risks of downward mobility. This may indicate that such unions represented lower productivity because the wife was older, without this disadvantage being compensated by property or income to the same degree as in husband-older heterogamous marriages.

Almost all kinds of geographic exogamy appear to have increased the probability of downward social mobility. The magnitudes of the effects were comparable to those of wife-older heterogamy. Men and women in couples in which at least one of the spouses came from places outside the parish of residence and its neighboring parishes were more likely to decline in SES, which may have been connected to lower access to important networks in the place of residence, or to exclusion of migrants more generally. However, there is also a positive effect of exogamy on upward mobility 
when both spouses came from outside the area. These are the couples we assume to have had the lowest degree of access to local networks, and who could be expected to have faced the greatest difficulties in socioeconomic advancement. One reason for their higher probability of upward mobility might be that this group contained a fraction of people who were positively selected, e.g., for employment in higher occupations, skilled work at one of the manors in the area, or in professional or clerical positions by the church or state. The social advancement of married migrants may also have reflected a generally higher productivity among migrants due to the positive selfselection in the migratory process, which is not captured in the variables included in the regressions. To the extent that this is true, it raises the question of why we could see no similar positive effect on upward mobility for people in exogamous marriages in which only one of the spouses was a migrant.

Finally, the separate logit models in Table 6, where all SES origins are included, show very similar results. This proves that the exclusion of the highest and lowest SES groups did not alter the pattern in any noticeable way.

Table 6: Marginal effects on directed intergenerational social mobility. Based on separate logit estimates

\begin{tabular}{|c|c|c|c|c|c|c|c|c|}
\hline & \multicolumn{4}{|c|}{ Men } & \multicolumn{4}{|c|}{ Women } \\
\hline & \multicolumn{2}{|c|}{ Upward } & \multicolumn{2}{|c|}{ Downward } & \multicolumn{2}{|c|}{ Upward } & \multicolumn{2}{|c|}{ Downward } \\
\hline & $d y / d x$ & $P>|z|$ & $d y / d x$ & $P>|z|$ & $d y / d x$ & $\mathrm{P}>|z|$ & $d y / d x$ & $P>|z|$ \\
\hline Pred.probability & 0.216 & & 0.478 & & 0.199 & & 0.524 & \\
\hline \multicolumn{9}{|l|}{ SES at birth } \\
\hline Higher occupations & NA & & 0.070 & 0.340 & NA & & 0.128 & 0.060 \\
\hline Freeholders & ref & & ref & & ref & & ref & \\
\hline Tenants & 0.101 & 0.056 & -0.010 & 0.823 & -0.028 & 0.495 & 0.117 & 0.009 \\
\hline Skilled & 0.112 & 0.187 & -0.178 & 0.210 & 0.092 & 0.182 & 0.012 & 0.854 \\
\hline Semi-landless & 0.387 & 0.000 & -0.286 & 0.000 & 0.196 & 0.001 & -0.214 & 0.000 \\
\hline Lower skilled & 0.316 & 0.000 & -0.231 & 0.000 & 0.229 & 0.000 & -0.177 & 0.000 \\
\hline Unskilled & 0.497 & 0.000 & NA & & 0.317 & 0.000 & NA & \\
\hline \multicolumn{9}{|l|}{ Social homogamy } \\
\hline Homogamous & ref & & ref & & ref & & ref & \\
\hline Hypergamous & 0.127 & 0.000 & -0.051 & 0.191 & 0.147 & 0.000 & -0.060 & 0.151 \\
\hline Hypogamous & -0.065 & 0.030 & 0.213 & 0.000 & -0.115 & 0.000 & 0.288 & 0.000 \\
\hline NA & 0.034 & 0.286 & 0.140 & 0.000 & -0.031 & 0.254 & 0.152 & 0.000 \\
\hline
\end{tabular}


Table 6: (Continued)

\begin{tabular}{|c|c|c|c|c|c|c|c|c|}
\hline & \multicolumn{4}{|c|}{ Men } & \multicolumn{4}{|c|}{ Women } \\
\hline & \multicolumn{2}{|c|}{ Upward } & \multicolumn{2}{|c|}{ Downward } & \multicolumn{2}{|c|}{ Upward } & \multicolumn{2}{|c|}{ Downward } \\
\hline & $\mathrm{dy} / \mathrm{dx}$ & $\mathrm{P}>|\mathrm{z}|$ & $\mathrm{dy} / \mathrm{dx}$ & $\mathrm{P}>|\mathrm{z}|$ & $\mathrm{dy} / \mathrm{dx}$ & $\mathrm{P}>|\mathrm{z}|$ & $\mathrm{dy} / \mathrm{dx}$ & $P>|z|$ \\
\hline \multicolumn{9}{|l|}{ Age homogamy } \\
\hline Homogamous & ref & & ref & & ref & & ref & \\
\hline Husband $3+$ older & 0.006 & 0.797 & -0.009 & 0.749 & -0.018 & 0.387 & -0.045 & 0.124 \\
\hline Wife $3+$ older & -0.025 & 0.383 & 0.087 & 0.038 & -0.011 & 0.732 & 0.128 & 0.002 \\
\hline \multicolumn{9}{|l|}{$\begin{array}{l}\text { Geographical } \\
\text { endogamy }\end{array}$} \\
\hline Endogamous & ref & & ref & & ref & & ref & \\
\hline $\begin{array}{l}\text { Exogamous, hu. } \\
\text { outside }\end{array}$ & -0.002 & 0.936 & 0.111 & 0.007 & 0.028 & 0.355 & 0.092 & 0.019 \\
\hline $\begin{array}{l}\text { Exogamous, wi. } \\
\text { outside }\end{array}$ & -0.028 & 0.321 & 0.110 & 0.004 & 0.019 & 0.534 & 0.144 & 0.000 \\
\hline $\begin{array}{l}\text { Exogamous, both } \\
\text { outside }\end{array}$ & 0.042 & 0.144 & 0.039 & 0.286 & 0.071 & 0.016 & 0.102 & 0.007 \\
\hline N & 1797 & & 1704 & & 1803 & & 1689 & \\
\hline LR chi2 & 320.1 & & 241.2 & & 365.3 & & 338.0 & \\
\hline Prob > chi2 & 0.000 & & 0.000 & & 0.000 & & 0.000 & \\
\hline
\end{tabular}

Note: Based on separate logit estimations excluding highest SES in upward estimation and lowest SES in downward estimation. Model also controls for parish, year of birth and year of birth squared.

Source: See Table 1.

\section{Conclusions}

From previous studies, we know that marriages in preindustrial rural Sweden were characterized by a tendency towards social homogamy and age homogamy, even as geographic exogamy was always important, and became increasingly so over the course of $19^{\text {th }}$-century. A comprehensive analysis of these outcomes shows that the socioeconomic dimension was the most significant one (Dribe and Lundh 2009a). We also know that social homogamy was the main strategy of landholding peasants, which to some extent produced social homogamy among the landless and semi-landless groups (Dribe and Lundh 2005a). Marriage was not mainly a matter of individual love and affection, but a family business with the aim of pooling resources in order to secure social reproduction and old age care for the parents.

In this study, the focus has been on the association between partner selection and SES attainment and intergenerational SES mobility. More specifically, we have tried to assess the effects of partner selection according to SES origin, age, and place of birth, 
controlling for the individuals' social origins and birth dates. We found that partner selection had a powerful impact on SES attainment. Compared to being homogamously married, SES hypergamy had a positive effect on attaining higher SES for both men and women. By contrast, being hypogamously married had the opposite, negative effect on SES attainment for both sexes.

Hypergamous marriages also increased the probability of upward SES mobility for both men and women. Hypogamous marriages, on the other hand, lowered the likelihood of upward SES mobility, and increased the risk of downward mobility. From the magnitude of effects, we concluded that hypergamy was more important for upward mobility than hypogamy was for downward mobility.

Thus, we found a clear ranking of marriage strategies as far as SES attainment and mobility were concerned. Marrying up was the best way to end up in the middle or higher part of the SES ranking, and also for social advancement. Marrying down had the opposite effect: it lead to lower SES attainment, and was correlated to downward SES mobility. A homogamous marriage strategy was a good choice for individuals of higher SES origin aiming at maintaining rather than improving SES attainment.

Interestingly, we also found some effects of age heterogamy on social attainment and mobility. Husband-older heterogamy improved SES attainment relative to being married age-homogamously. Wife-older heterogamy had the opposite effect, lowering socioeconomic attainment. For SES mobility, we also found a quite substantial effect of wife-older heterogamy on downward mobility. One possible explanation for this might be that such unions had fewer productivity-related assets.

Finally, the effects of geographic exogamy on socioeconomic attainment were in most cases small and not statistically significant, except for exogamously married women born outside the area. The results indicated lower SES attainment for these women relative to endogamously married women. For SES mobility, we found that almost all types of geographic exogamy increased the probability of downward SES mobility. This could be due to insufficient access to local networks, and to exclusion of migrants in general. However, we also found a positive effect on upward mobility of exogamy when both spouses came from outside the area, which might have been related to positive selection of migrants.

As a whole, the results presented in this article point to the important interactions between partner selection and social reproduction in a wider sense. It is difficult, if not impossible, to determine the causal effects of marriage and partner choice on SES attainment and mobility, but it seems reasonable to conclude that there were strong associations between the two, and that partner selection was an important aspect of an individual's socioeconomic attainment and mobility, in addition to his or her inherited resources and access to networks. Marrying someone from the same geographic background, and from the same or higher SES, clearly helped individuals in avoiding 
downward mobility; and, in several cases, we saw that finding the right partner was also instrumental for social advancement.

\section{Acknowledgement}

We are grateful for comments and suggestions made by the participants at the IUSSP seminar "Social Mobility and Demographic Behavior: A Long Term Perspective," UCLA, Los Angeles, 11-13 December 2008. Martin Dribe acknowledges financial support from the Linnaeus Centre for Economic Demography, Lund University, financed by The Swedish Research Council. 


\section{References}

Allen, R.C., Bengtsson, T., and Dribe, M. (eds.) (2005). Living standards in the past: New perspectives on well-being in Asia and Europe. Oxford: Oxford University Press.

Arizzabalaga, M.-P. (2005). Pyrenean marriage strategies in the nineteenth century: The French Basque case. International Review of Social History 50(Suppl.): 93-122. doi:10.1017/S0020859005002087.

Bengtsson, T., Campbell, C., and Lee, J.Z. (2004). Life under pressure. Mortality and living standards in Europe and Asia, 1700-1900. Cambridge, MA: MIT Press.

Bengtsson, T. and Dribe, M. (2006). Deliberate control in a natural fertility population: southern Sweden 1766-1865. Demography 43(4): 727-746. doi:10.1353/dem.2006.0030.

Blau, P.M. and Duncan, O.D. (1967). The American Occupational Structure. New York: Wiley.

Blau, P.M., Beeker, C., and Fitzpatrick, K.M. (1984). Intersecting social affiliations and intermarriage. Social Forces 62(3): 585-606. doi:10.2307/2578701.

Bourdieu, P. (1976). Marriage strategies as strategies of social reproduction. In: Forster, R. and Ranum, O. (eds.). Family and society. Selections from the Annales, Économies, Sociétés, Civilisations. Baltimore: The Johns Hopkins University Press.

Bras, H. and Kok, J. (2005). 'They live in indifference together': Marriage mobility in Zeeland, The Netherlands, 1796-1922. International Review of Social History 50(Suppl.): 247-274. doi:10.1017/S0020859005002130.

Breen, R. and Jonsson, J.O. (2005). Inequality of opportunity in comparative perspective: Recent research on educational attainment and social mobility. Annual Review of Sociology 31(1): 223-243. doi:10.1146/annurev.soc. 31.041304.122232.

Bull, H.H. (2005). Deciding whom to marry in a rural two-class society: Social homogamy and constraints in the marriage market in Rendalen, Norway, 17501900. International Review of Social History 50(Suppl.): S43-64. doi:10.1017/S0020859005002063.

Cherlin, A.J. (2004). The deinstitutionalization of American marriage. Journal of Marriage and Family 66(4): 848-861. doi:10.1111/j.0022-2445.2004.00058.x. 
Chiswick, B.R. (1978). The effects of Americanization of the earnings of foreign-born men. Journal of Political Economy 86(5): 897-921. doi:10.1086/260717.

Coontz, S. (2004). The world historical transformation of marriage. Journal of Marriage and Family 66(4): 974-979. doi:10.1111/j.0022-2445.2004.00067.x.

De Graf, P.M., Ganzeboom, H.G.B., and Kalmijn, M. (1989). Cultural and economic dimensions of occupational status. In: Jansen, W., Dronkers, J., and Verrips, K. (eds.). Similar or different? Continuities in Dutch research on social stratification and social mobility. Amsterdam: SISWO.

Dewald, J. (1996). The European nobility, 1400-1800. Cambridge: Cambridge University Press.

Dribe, M. (2000). Leaving home in a peasant society. Economic fluctuations, household dynamics and youth migration in southern Sweden, 1829-1866. Södertälje: Almqvist \& Wiksell International.

Dribe, M. (2003) Liv och rörelse. Familj och flyttningar i 1800-talets svenska bondesamhälle. Hedemora: Gidlunds.

Dribe, M. and Lundh, C. (2005a). Finding the right partner. Rural homogamy in nineteenth-century Sweden. International Review of Social History 50(Suppl.): 149-178. doi:10.1017/S0020859005002105.

Dribe, M. and Lundh, C. (2005b). Gender aspects of inheritance strategies and land transmission in rural Scania, Sweden, 1720-1840. History of the Family 10(3): 293-308. doi:10.1016/j.hisfam.2005.03.005.

Dribe, M. and Lundh, C. (2005c). Retirement as a strategy for land transmission: A micro-study of pre-industrial rural Sweden. Continuity and Change 20(2) 16591. doi:10.1017/S0268416005005497.

Dribe, M. and Lundh, C. (2009a). Status homogamy in the preindustrial marriage market. Partner selection according to age, social origin, and place of birth in nineteenth century rural Sweden. Journal of Family History 34(4): 387-406. doi:10.1177/0363199009344708.

Dribe, M. and Lundh, C. (2009b). Partner choice and intergenerational occupational mobility. The case of nineteenth century rural Sweden. Continuity and Change 24(3): 487-512. doi:10.1017/S0268416009990178.

Dribe, M. and Svensson, P. (2008). Social mobility in nineteenth century rural Sweden - a micro level analysis. Scandinavian Economic History Review 56(2): 122141. doi:10.1080/03585520802137194. 
Edvinsson, S. (1992) Den osunda staden. Sociala skillnader i dödlighet i 1800-talets Sundsvall. Umeå: Report no. 7 from the Demographic Database, Umeå University.

Erikson, R. and Goldthorpe, J.H. (1993). The constant flux. A study of class mobility in industrial societies. Oxford: Clarendon Press.

Eriksson, I. and Rogers, J. (1978). Rural labor and population change. Social and demographic developments in East-central Sweden during the nineteenth century. Uppsala: Almqvist \& Wiksell International.

Ferrie, J.P. (1999). Yankeys now. Immigrants in the antebellum U.S. 1840-1860. Oxford: Oxford University Press.

Flandrin, J.-L. (1975). Les amours paysannes (XVIe-XIXe siècle). Paris: GallimardJulliard.

Gordon, M.M. (1964). Assimilation in American life. New York: Oxford University Press.

Granlund, J. (1969). Bröllopsfunktionärer. Fataburen 64: 133-148.

Hajnal, J. (1983). Two kinds of pre-industrial household formation system. In: Wall, R., Laslett, P., and Robin, J. (eds.). Family Forms in Historic Europe. Cambridge: Cambridge University Press.

Harnesk, B. (1990). Legofolk. Drängar, pigor och bönder i 1700- och 1800-talens Sverige. Umeå: Acta Universitatis Umensis, Umeå Studies in the Humanities 96.

Hersovici, S. (1998). Migration and economic mobility: Wealth accumulation and occupational change among antebellum migrants and persisters. Journal of Economic History 58(4): 927-956. doi:10.1017/S0022050700021677.

Hurwich, J.J. (1998). Marriage strategy among the German nobility, 1400-1699. Journal of Interdisciplinary History 29(2): 169-195. doi:10.1162/002219598551661.

Jonsson, J.O. and Erikson, R. (2000). Understanding educational inequality: The Swedish experience. L'Année Sociologique 50(2): 345-382.

Kalmijn, M. (1991). Status homogamy in the United States. American Journal of Sociology 97(2): 496-523. doi:10.1086/229786.

Kalmijn, M. (1994). Assortative mating by cultural and economic occupational status. American Journal of Sociology 100(2): 422-452. doi:10.1086/230542. 
Kalmijn, M. (1998). Intermarriage and Homogamy: Causes, patterns, trends. Annual Review of Sociology 24(1): 395-421. doi:10.1146/annurev.soc.24.1.395.

Laslett, P. (1977). Family life and illicit love in earlier generations. Cambridge: Cambridge University Press. doi:10.1017/CBO9780511522659.

Le Goff, J. and Schmitt, J-C. (eds.) (1981). Le charivari. Paris: École des Hautes Études en Sciences Sociales.

Livi Bacci, M. (1991). Population and nutrition. An essay on European demographic history. Cambridge: Cambridge University Press.

Long, J. (2005). Rural-urban migration and socioeconomic mobility in Victorian Britain. Journal of Economic History 65(1): 1-35. doi:10.1017/S0022050705050011.

Lundh, C. (1999). The social mobility of servants in rural Sweden in the nineteenth century. Continuity and Change 14(1): 57-89. doi:10.1017/S0268416099003264.

Maas, I. and Van Leeuwen, M.H.D. (2002). Industrialization and intergenerational mobility in Sweden. Acta Sociologica 45(3): 179-194. doi:10.1080/00016990260257175.

Maas, I. and Van Leeuwen, M.H.D. (2005). Total and relative endogamy by social origin: A first international comparison of changes in marriage choices during the nineteenth century. International Review of Social History 50(S13): 275295. doi:10.1017/S0020859005002142.

Manfredini, M. (2003). Families in motion: The role and characteristics of household migration in a 19th-century rural Italian parish. History of the Family 8(2): 317343. doi:10.1016/S1081-602X(03)00031-9.

Matovic, M. (1990). Migration, family formation, and choice of marriage partners in Stockholm, 1860-1890. In: van der Woude, A., de Vries, J., and Hayami, A. (eds.). Urbanization in history. A process of dynamic interaction. Oxford: Clarendon Press.

Mitterauer, M. (1988). Ungdomstidens sociala historia (Sozialgeschichte der Jugend). Göteborg: Röda bokförlaget.

Mitterauer, M. and Sieder, R. (1982). The European family. Patriarchy to partnership from the middle ages to the present. Chicago: The University of Chicago Press. 
Oris, M. (2000). The age at marriage of migrants during the industrial revolution in the region of Liège. History of the Family 5(4): 391-413. doi:10.1016/S1081602X(00)00052-X.

Razzel, P. and Spence, C. (2006). The hazard of wealth: Adult mortality in pretwentieth-century England. Social History of Medicine 19(3): 381-405. doi:10.1093/shm/hk1048.

Schoen, R. and Woolredge, J.D. (1989). Marriage choices in North Carolina and Virginia, 1969-71 and 1979-81. Journal of Marriage and the Family 51(2):465-481. doi: $10.2307 / 352508$.

Schofield, R. (1976). The relationship between demographic structure and environment in pre-industrial Western Europe. In Conze, W. (ed.). Sozialgeschichte der Familie in der Neuzeit Europas. Stuttgart: Ernst Klett.

Segalen, M. (1983). Love and power in the peasant family: Rural France in the nineteenth century. Chicago: University of Chicago Press.

Shorter, E. (1977). The making of the modern family. New York: Fontana Books.

Sjaastad, L.A. (1962). The costs and returns of human migration. Journal of Political Economy 70(1): 80-93. doi:10.1086/258726.

Skinner, G.W. (1997). Family systems and demographic processes. In: Kertzer, D.I. and Fricke, T. (eds.). Anthropological demography. Towards a new synthesis. Chicago: The University of Chicago Press.

Smith, D.S. (1983). Differential mortality in the United States before 1900. Journal of Interdisciplinary History 13(4): 735-759. doi:10.2307/203888.

Statistics Sweden (1999). Befolkningsutvecklingen under 250 år. Stockholm: SCB.

Stewart, J.I. (2006). Migration to the agricultural frontier and wealth accumulation, 1860-1870. Explorations in Economic History 43(4): 547-577. doi:10.1016/j.eeh.2005.08.002.

Stone, L. (1977). The family, sex and marriage in England 1500-1800. London: Weidenfeldt and Nicholson.

Stone, L. and Fawtier, J.C. (1984). An open elite? England 1540-1880. Oxford: Oxford University Press.

Taylor, P.A. and Glenn, N.D. (1976). The utility of education and attractiveness for females - status attainment through marriage. American Sociological Review 41(3):484-497. doi:10.2307/2094255. 
Tsuya, N.O., Feng, W., Alter, G., and Lee, J.Z. (2010). Prudence and pressure. Reproduction and human agency in Europe and Asia, 1700-1900. Cambridge, MA: MIT Press.

Udry, J.R. (1977). The importance of being beautiful. A reexamination and racial comparison. American Journal of Sociology 83(1):154-160. doi:10.1086/226511.

Van Bavel, J., Peeters, H., and Matthijs, K. (1998). Connections between intergenerational and marital mobility. A case study: Leuven, 1830-1910. Historical Methods 31(3): 122-134. doi:10.1080/01615449809601195.

Van de Putte, B. (2003). Homogamy by geographical origin: Segregation in nineteenthcentury Flemish cities (Gent, Leuven, and Aalst). Journal of Family History 28(3): 364-90. doi:10.1177/0363199003256015.

Van de Putte, B. (2006). Social power and class formation in the nineteenth century. How to measure class from occupation? Paper presented at the European Social Science History Conference, Amsterdam, March 2006.

Van de Putte, B., Van Poppel, F., Vanassche, S., Sanchez, M., Jidkova, S., Eeckhaut, M., Oris, M., and Matthijs, K. (2009). The rise of age homogamy in 19th century Western Europe. Journal of Marriage and Family 71(5): 1234-1253. doi:10.1111/j.1741-3737.2009.00666.x.

Van Leeuwen, M.H.D. and Maas, I. (1991). Log-linear analysis of changes in mobility patterns. Some models with an application to the Amsterdam upper classes in the second half of the nineteenth century. Historical Methods 24(2): 66-79.

Van Leeuwen, M.H.D. and Maas, I. (1996). Long-term social mobility: Research agenda and a case study (Berlin, 1825-1957). Continuity and Change 11(3): 399-433. doi:10.1017/S0268416000003477.

Van Leeuwen, M.H.D. and Maas, I. (2002). Partner choice and homogamy in the nineteenth century: Was there a sexual revolution in Europe? Journal of Social History 36(1): 101-123. doi:10.1353/jsh.2002.0111.

Van Leeuwen, M.H.D., Maas, I., and Miles, A. (2002). HISCO. Historical International Standard Classification of Occupations. Leuven: Leuven University Press.

Van Poppel, F. and Nelissen, J. (1999). The proper age to marry: Social norms and behavior in nineteenth-century Netherlands. History of the Family 4(1): 51-75. doi:10.1016/S1081-602X(99)80265-6. 
Dribe \& Lundh: Marriage choices and social reproduction

Winberg, C. (1975). Folkökning och proletarisering. Kring den social strukturomvandlingen på Sveriges landsbygd under den agrara revolutionen. Doctoral Dissertation, Department of History, University of Gothenburg. 